\title{
A COMPARISON OF PROCEDURES FOR INCREASING BLOOD FLOW TO LIMBS USING AN IMPROVED OPTICAL PLETHYSMOGRAPH
}

\author{
By G. W. WRIGHT AND KENTON PHELPS \\ (From the Departments of Physiology and Surgery of Western Reserve University \\ Medical School, Cleveland)
}

(Received for publication September 11, 1939)

Measuring the minute volume of blood flow through an extremity at rest, or in response to a physiological stimulus, offers a useful means of evaluating the status of its vascular bed. Hewlett and Van Zwaluwenburg (1) used for this purpose a plethysmograph based upon the principle demonstrated by Brodie (2) wherein sudden occlusion of the veins draining the limb produces an increase in limb size, which can be used as a measure of arterial inflow. If a limb is enclosed in a rigid container the increase in volume can be recorded in a variety of ways. Hewlett and Van Zwaluwenburg (3) used air conduction and optical recording; more recently others have used water or water and air conduction with a Brodie bellows, Gad volume recorder, or a piston recorder. Experience has shown us that these latter methods have concealed errors which become apparent when replaced by air conduction and optical recording. These are: $(a)$ errors in calibration due to a non-rigid closure of the open end of the plethysmograph, $(b)$ errors due to involuntary movement of the extremity into and out of the plethysmograph, (c) errors produced by rising intravascular tension secondary to venous obstruction, $(d)$ errors due to the effect of displacement of blood from beneath the collecting cuff. This report concerns itself with a study of these errors, with means of eliminating them, and with a comparison of five procedures commonly used to produce dilatation of the vascular bed in the lower extremity.

\section{APPARATUS}

A modification of the Hewlett and Van Zwaluwenburg leg plethysmograph (3) was devised which has the following chief advantages: (a) greater accuracy in calculation of minute blood flow, (b) ease and accuracy of calibration, (c) rigid, air-tight, non-constricting closure of the open end, $(d)$ ease of application.

The plethysmograph (Figure 1) is made of cast aluminum, formed like a boot with a capacity of $6,500 \mathrm{cc}^{1}$ It is bivalved on its long axis and, when fitted together about the leg, is closed with a rubber gasket. A thin rubber pad (not shown in drawing) is interposed between the sole of the foot and the boot wall upon which it rests. To keep the air surrounding the limb at a constant and at any desired temperature, the plethysmograph is immersed in a water bath. After immersion, the boot is anchored firmly by a sliding gate, made water-tight with a sponge-rubber gasket (Figure 1).

The space between the leg and boot wall at its mouth is filled with fast-setting plaster of paris (Figure 1). A cardboard ring supported by a ledge in the boot wall prevents the plaster while in its liquid state from falling into the plethysmograph. Before the plaster becomes firm, the leg is moved from side to side to create a $2 \mathrm{~mm}$. space between the skin and adjacent plaster. When the plaster is firmly set the leg is withdrawn 2 to $3 \mathrm{~cm}$. and melted Unna paste is applied in a thick layer to the skin surface which is to be in contact with the plaster. The leg is quickly returned to its natural position in the boot, the Unna paste (Figure 1) completely filling the crevice between the skin and plaster. A generous application of melted Unna paste applied over the outer surface of the plaster and for a distance of $3 \mathrm{~cm}$. upon the skin of the leg completes an air-tight, rigid closure of the plethysmograph without producing any venous obstruction. The elasticity of the Unna paste permits slight voluntary controlled movement of the limb which relieves the cramplike sensations accompanying prolonged experiments.

Volume changes of the limb within the plethysmograph are recorded optically with a Frank segment capsule joined to the plethysmograph by

1 The plethysmograph for the foot alone has a capacity of $3,200 \mathrm{cc}$. 

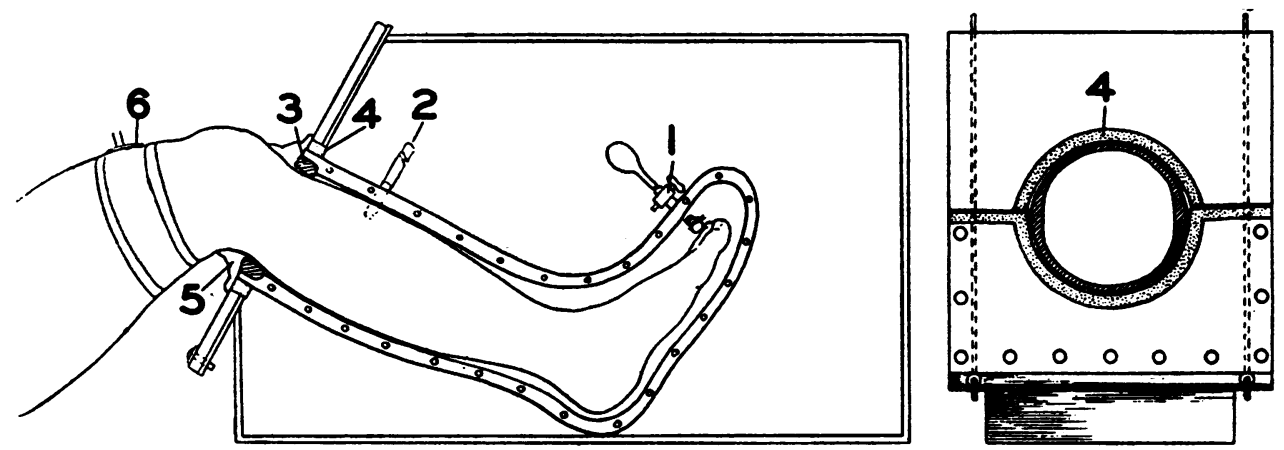

Fig. 1. Diagram of Boot Plethysmograph

(1) Calibrating stopcock, (2) rubber tube connecting plethysmograph with Frank segment capsule, (3) plaster of paris seal, (4) sponge rubber gasket, (5) Unna paste seal, (6) collecting cuff.

a piece of stiff rubber tubing $15 \mathrm{~cm}$. long with a bore of $1.2 \mathrm{~cm}$.

Sudden obstruction to venous drainage from the limb is accomplished in the conventional manner by a blood pressure cuff (hereafter referred to as the "collecting cuff") $6 \mathrm{~cm}$. in diameter (Figure 1) connected to a reservoir containing air at the desired pressure. The moment at which the collecting cuff is inflated is recorded by a Frank segment capsule (Figure 2).
It is necessary (for reasons to be discussed later in the paper) to have the plethysmograph open to the atmosphere when the collecting cuff is inflated and for a period of one second thereafter. This is accomplished as follows: A stopcock is introduced in the tube connecting the pressure reservoir with the collecting cuff and another in a side arm from the tube connecting the plethysmograph with the Frank segment capsule. A solenoid actuated by a time switch op-

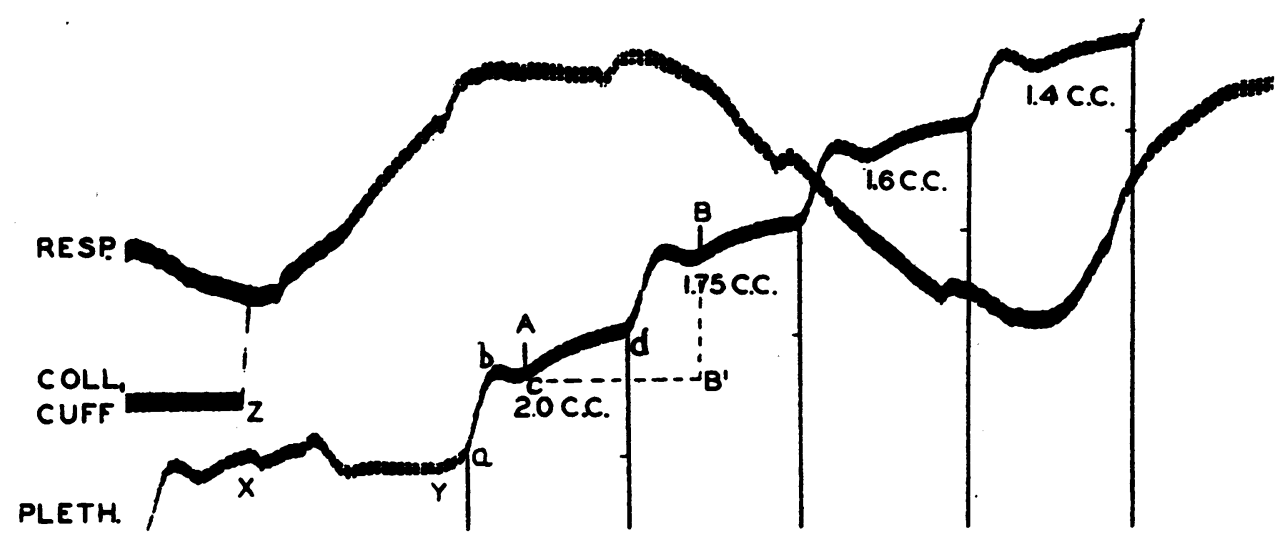

Fig. 2. Optical Record of Phasic Blood Flow in Leg

Resp. Movements of chest wall with down stroke denoting inspiration.

Coll. Cuff. Pressure changes in the collecting cuff.

Pleth. Limb volume changes as recorded by the plethysmograph.

$Z$. Denotes moment of collecting cuff inflation.

$X-Y$. Interval during which plethysmograph is open.

$a-b$. Rapid arterial inflow phase.

$b-c$. Arterial outflow phase.

$c-d$. Slow arterial inflow phase.

$A-B$. Cycle from which blood flow calculation is made.

$B-B$. Ordinate representing net arterial inflow for cycle $A-B$.

Numbers represent value in cc. of the net arterial inflow for each successive cycle. 
erates both of these stopcocks simultaneously. When the timing switch is closed the solenoid opens both stopcocks. Thus the plethysmograph is open (Figure 2X) to the atmosphere at the time the collecting cuff is inflated. When the timing switch opens one second later, the solenoid is released and a spring mechanism closes the plethysmograph stopcock, thus allowing the volume changes of the limb to be recorded (Figure 2Y).

Calibration of the plethysmograph is accomplished by injecting or withdrawing a measured volume of fluid through a stopcock (Figure 1) into a small rubber bag within the plethysmograph. This must be done with the extremity in situ and with the arterial inflow completely obstructed by pressure in the collecting cuff.

The natural frequency of the apparatus in situ ranges from 50 to 100 per second over such a range of sensitivity that a $1 \mathrm{cc}$. increase in the fluid content of the plethysmograph produces a light beam excursion of 2 to $10 \mathrm{~cm}$. at a projection distance of 1.5 meters.

Immobility of the limb inside of the plethysmograph is checked at the beginning of and during each experiment by completely occluding the artery and observing whether or not any variation in the plethysmograph volume occurs synchronously with breathing. When involuntary movement of the limb into and out of the plethysmograph is noted, it is easily abolished by placing a wide gauze bandage across the superior margin of the patella and tying each end to the water bath, thus anchoring the limb without producing any venous obstruction.

Respiratory excursions of the chest wall are recorded by a Frank segment capsule connected with a pneumograph. The volume of the limb contained in the plethysmograph is determined by displacement. Brachial arterial blood pressure determinations are made by a mercury manometer and auscultation immediately after each measurement of blood flow.

\section{EXPERIMENTAL PROCEDURE}

For these studies the subject lies upon his back in a Gatch bed with the hip and knee flexed about $35^{\circ}$ and the head and shoulders slightly elevated, thus bringing the heart and the extremity being measured approximately to the same level. This position is chosen because it pre- vents the development of hioh venous pressure in the limb and is known to be the posil.un best tolerated with comfort over a period of several hours. To obtain standard experimental conditions, the following requirements are observed: (a) severe exercise is prohibited for 24 hours prior to a study, (b) smoking is not allowed within the hour preceding and during a study, (c) unnecessary talking and other disturbing influences are avoided during the observation, $(d)$ studies are begun 3 to 4 hours after the last meal, $(e)$ the subject, clad in trunks, reclines quietly for 45 minutes in a room kept at a constant temperature between 28 and $30^{\circ}$ before being studied, $(f)$ a lapse of 30 minutes is allowed after completing the application of the boot plethysmograph before records are taken. This allows the flow of blood to assume a constant level and the heat in the setting plaster and melted Unna paste to dissipate.

\section{METHOD OF CALCULATING BLOOD FLOW}

A typical record is shown in Figure 2. The upper curve denotes respiratory excursions of the chest wall, inspiration being represented as a down stroke. The moment of inflation of the collecting cuff is signalled by the sharp rise $(Z)$ of the second curve. The lower curve (time marker equals .04 seconds) is a record of the variations in volume of the limb contained in the plethysmograph. It is noted that with each pulse there is a rapid increase in limb volume $(a-b)$ followed by a small decrease $(b-c)$, after which there is a gradual further increase $(c-d)$. In terms of blood flow each pulse shows an initial large inflow followed by a small outflow which in turn is followed by a gradual inflow of blood. Actually each pulse (Figure 2, $a-d$ ) represents a net inflow of arterial blood. That portion of the cycle $(b-c)$ representing outflow merits more detailed discussion later.

It is apparent from these variations during a single pulse that the net inflow (a single complete cycle) is the smallest unit that can be used for measuring blood flow. Methods using the gradient of any portion of a cycle for calculating blood flow are distinctly in error. As the curve rises, each successive beat forces a smaller net volume of blood into the leg because of rising venous resistance. In this curve (Figure 2) the net flow per successive beat is $2.0,1.75,1.6,1.4 \mathrm{cc}$. This fact introduces an error in all procedures using the volume of several successive beats to calculate minute blood flow. To avoid the error introduced by a rising venous resistance, the first complete cycle following inflation of the collecting cuff should be used as the unit most nearly representing true arterial inflow. Use of this cycle, however, is complicated by the fact that the collecting cuff as it is inflated squeezes an appreciable volume of blood from the vessels underlying it into the tissues contained in the plethysmograph. The effect of the displaced blood on the limb volume cannot be differentiated by the plethysmograph from the effect of normal arterial inflow. Optical recording methods also show that this effect cannot be avoided by varying the size or distances of the collecting cuff from the plethysmograph as has been supposed by 
investigators using less sensitive, low frequency apparatus. Since this action of the collecting cuff cannot be prevented, the first cycle following the termination of its effect becomes the earliest available cycle for measuring blood flow. The time required to complete the displacement of blood from beneath the collecting cuff is determined by completely occluding the arterial inflow to the leg with an inflated cuff on the mid-thigh and then inflating the collecting cuff in its usual position with a pressure of $80 \mathrm{~mm}$. of mercury. The increase in limb volume within the plethysmograph (Figure $3, A-B$ ) re-

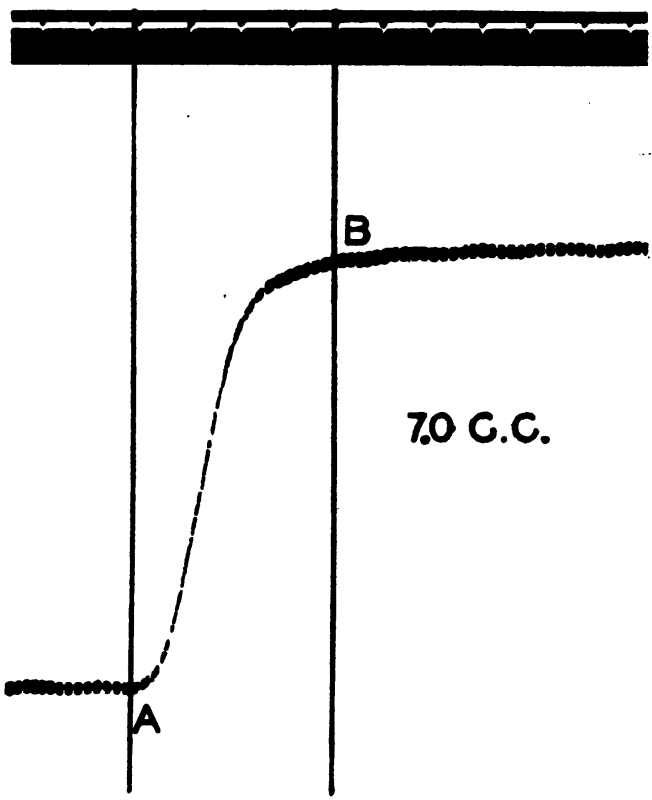

Fig. 3. Displacement of Fluid from Beneath Collecting Cuff

$A-B$. Magnitude of and time required for displacement of fluid from beneath collecting cuff.

sulting from displacement of fluid by the collecting cuff, even when of large magnitude, never requires more than 1.2 seconds. Consequently, the undesirable effect of the collecting cuff can be circumvented by measuring the increase in limb volume for one pulse cycle beginning at a point (Figure 2-A) 1.6 seconds after inflating the collecting cuff, regardless of the place in the cycle at which this point falls. In order to nullify the error that might be introduced by a sinus arrhythmia, the duration of this cycle (Figure 2, $A-B$ ) must be equal to the average of several cycles recorded during the flow measurement. The ordinate value $B-B^{1}$ representing the net arterial inflow for one cycle is converted to cubic $\mathrm{cm}$. and the net arterial blood flow is expressed in the conventional manner of cc. per $100 \mathrm{cc}$. limb substance per minute.

The sudden increase in limb volume produced by the massaging action of the collecting cuff is not recorded (Figure 2, $X-Y$ ) by the simple expedient of having the plethysmograph open to the atmosphere during the time this event occurs. This is accomplished by the apparatus described earlier.

In addition to errors resulting from inadequate apparatus, imperfections in technique may be introduced by variations in the individual being studied. Observations show that records taken more frequently than every 2 minutes result in progressively smaller blood flows. Apparently sufficient time ( 2 minutes) must be allowed after each test for the accumulated blood to leave the tissues in order to restore normal dynamic conditions.

TABLE I

Constancy of leg-foot blood flows taken at 2-minute intervals

\begin{tabular}{c|c|c|c|c|c|c|c|c}
\hline \hline Time & $\begin{array}{c}\text { Blood } \\
\text { flow }\end{array}$ & $\begin{array}{c}\text { Blood } \\
\text { pres- } \\
\text { sure }\end{array}$ & $\begin{array}{c}\text { Heart } \\
\text { rate }\end{array}$ & $\begin{array}{c}\text { Room } \\
\text { tem- } \\
\text { pera- } \\
\text { ture }\end{array}$ & $\begin{array}{c}\text { Bath } \\
\text { tem- } \\
\text { pera- } \\
\text { ture }\end{array}$ & $\begin{array}{c}\text { Boot } \\
\text { tem- } \\
\text { pera- } \\
\text { ture }\end{array}$ & $\begin{array}{c}\text { Oral } \\
\text { tem- } \\
\text { pera- } \\
\text { ture }\end{array}$ & $\begin{array}{c}\text { Cuff } \\
\text { pres- } \\
\text { sure }\end{array}$ \\
\hline $9: 36$ & 8.0 & $104 / 66$ & 71 & 28 & 45 & 43 & 37 & 80 \\
$9: 38$ & 7.4 & $104 / 66$ & 65 & 28 & 45 & 43 & 37 & 80 \\
$9: 40$ & 7.6 & $104 / 66$ & 73 & 28 & 45 & 43 & 37 & 80 \\
$9: 42$ & 7.4 & $104 / 66$ & 71 & 28 & 45 & 43 & 37 & 80 \\
$9: 44$ & 7.9 & $104 / 66$ & 71 & 28 & 45 & 43 & 37 & 80 \\
\hline
\end{tabular}

Blood flow is expressed in cc. per minute per $100 \mathrm{cc}$. leg tissue.

Blood pressure and cuff pressure are expressed in $\mathrm{mm}$. of mercury.

All temperatures are expressed in degrees centigrade.

TABLE II

Effect of blood pressure upon blood flow

\begin{tabular}{l|c|c|c|c|c|c|c|c}
\hline \hline Time & $\begin{array}{l}\text { Blood } \\
\text { flow }\end{array}$ & $\begin{array}{c}\text { Blood } \\
\text { pres- } \\
\text { sure }\end{array}$ & $\begin{array}{c}\text { Heart } \\
\text { rate }\end{array}$ & $\begin{array}{c}\text { Room } \\
\text { tem- } \\
\text { pera- } \\
\text { ture }\end{array}$ & $\begin{array}{c}\text { Bath } \\
\text { tem- } \\
\text { pera- } \\
\text { ture }\end{array}$ & $\begin{array}{c}\text { Boot } \\
\text { tem- } \\
\text { pera- } \\
\text { ture }\end{array}$ & $\begin{array}{c}\text { Oral } \\
\text { tem- } \\
\text { pera- } \\
\text { ture }\end{array}$ & $\begin{array}{c}\text { Cuff } \\
\text { pres- } \\
\text { sure }\end{array}$ \\
\hline $11: 00$ & 6.7 & $116 / 70$ & 69 & 28 & 28 & 28 & 37 & 75 \\
$11: 03$ & 6.6 & $116 / 70$ & 57 & 28 & 28 & 28 & 37 & 75 \\
$11: 12$ & 6.8 & $116 / 70$ & 58 & 28 & 28 & 28 & 37 & 75
\end{tabular}

HANDS IMMERSED IN WATER AT 11 DEGREES CENTIGRADE FOR 5 MINUTES

\begin{tabular}{l|l|l|l|l|l|l|l|l}
$11: 20$ & 8.4 & $130 / 82$ & 68 & 28 & 28 & 28 & 37 & 75 \\
\hline
\end{tabular}

It scarcely seems necessary to point out the absolute necessity of blood pressure observations for interpreting variations in blood flow. Nevertheless there is a conspicuous absence of such data in published reports concerning this subject. Table II shows the influence of blood pressure change upon the blood flow in the foot. It is apparent also from the contour of the phasic flow that if the heart rate is increased, even though there be no change in systolic or diastolic pressure, there may be an increase in the peripheral blood flow since it is the latter part of the cycle that is shortened.

Table III shows that the pressure in the collecting cuff can vary over a wide range with but little variation in the recorded blood flow. 
TABLE III

Effect of lowering the collecting cuff pressure upon the recorded blood flow

\begin{tabular}{c|c|c|c|c|c|c|c|c}
\hline \hline Time & $\begin{array}{l}\text { Blood } \\
\text { flow }\end{array}$ & $\begin{array}{c}\text { Blood } \\
\text { pres- } \\
\text { sure }\end{array}$ & $\begin{array}{c}\text { Heart } \\
\text { rate }\end{array}$ & $\begin{array}{c}\text { Room } \\
\text { tem- } \\
\text { pera- } \\
\text { ture }\end{array}$ & $\begin{array}{c}\text { Bath } \\
\text { tem- } \\
\text { pera- } \\
\text { ture }\end{array}$ & $\begin{array}{c}\text { Boot } \\
\text { tem- } \\
\text { pera- } \\
\text { ture }\end{array}$ & $\begin{array}{c}\text { Oral } \\
\text { tem- } \\
\text { pera- } \\
\text { ture }\end{array}$ & $\begin{array}{c}\text { Cuff } \\
\text { pres- } \\
\text { sure }\end{array}$ \\
\hline $8: 00$ & 3.7 & $120 / 72$ & 68 & 28 & 28 & 28.5 & 37 & 80 \\
$8: 04$ & 3.9 & $120 / 72$ & 69 & 28 & 28 & 28.5 & 37 & 60 \\
$8: 07$ & 3.8 & $120 / 72$ & 71 & 28 & 28 & 28.5 & 37 & 42 \\
$8: 09$ & 3.4 & $120 / 72$ & 68 & 28 & 28 & 28.5 & 37 & 35 \\
$8: 12$ & 3.3 & $120 / 72$ & 70 & 28 & 28 & 28.5 & 37 & 25 \\
$8: 15$ & 2.8 & $120 / 72$ & 70 & 28 & 28 & 28.5 & 37 & 15 \\
\hline
\end{tabular}

\section{The arterial backflow}

The record shown in Figure 2 reveals a brief reduction in limb size, $b-c$, which is due to an outflow of blood occurring in the presence of a pressure of $80 \mathrm{~mm}$. of mercury in the collecting cuff. The only channels by which blood can leave are the superficial and deep veins of the leg, the bone canals and the arteries. Escape via the veins under the inflated collecting cuff is excluded by $a$ priori considerations and also by the fact that it occurs during the first beat after inflating the cuff, i.e., at a time when the pressure in the veins cannot conceivably overcome that produced by the collecting cuff. Furthermore, it varies greatly in magnitude in different individuals and in the same individual under varying conditions; in fact, it may be entirely absent. Outflow of blood via vessels of the bones in the foot and leg is not plausible since these vessels join more superficial veins before they reach the collecting cuff. We agree with Hewlett and Van Zwaluwenburg (3) that by exclusion, the only conclusion tenable is that the reduction in limb size (Figure 2, b-c) represents arterial backflow. We believe it to be a phenomenon normally present in unimpeded blood flow in the extremities.

The forces responsible for arterial backflow arise in the following manner: The discharge of blood from the left ventricle into the aorta initiates a pressure wave which is rapidly propagated along the aorta and into its branches. This pressure wave accelerates the flow of blood in the regions through which it travels, producing a wave of accelerated blood flow. Upon reaching the terminal portions of the arterial tree, the momentum of this accelerated column of blood for a brief period forces more blood into the small arteries and arterioles than can flow from them into the capillaries. Consequently, for a moment blood accumulates in the distal end of the arterial tree. As the blood accumulates, it also decelerates and a portion of its energy of flow is converted into energy of lateral pressure. As a result, the pressure of the accumulated blood in the small arteries for a brief moment exceeds that of the blood in the larger arteries, and arterial backflow occurs.

The pressure relationships necessary to produce this arterial backflow have been found to exist in the limb of the dog by Hamilton and Dow (4) and in the lower extremity of the human by Hamilton, Woodbury and Harper (5). The demonstration of backflow in arteries as far distal as those of the foot requires that these vessels must be included in the oscillating arterial system, the reflected waves (not only pressure, but also actual fluid displacement) from which influence the contour of the arterial pulse in all segments proximally located. This view has previously been suggested by Hamilton (4) on the basis of arterial pressure measurements.

Figure 4 shows the phasic flow of blood at rest $(A)$ and after the application of local heat $(K)$. The backflow $(B-C)$ present normally is abolished $(D-E)$, presumably due to dilatation of the arterioles and a consequent lessening of blood accumulation in the small arteries with each heart beat.

Figure 5 shows the phasic and net arterial blood flow of the foot before $(H)$ and after $(I)$ inhalation of amyl nitrite and before $(J)$ and after $(K)$ sacral diathermy. Each of these procedures results in an increase of the initial inflow phase $(A-B)$, and an increase in the arterial backflow phase $(B-C)$, with a reduction in the net arterial inflow $(D-E)$. In spite of an increase in heart rate, the minute flow is reduced in each instance. Because of the increase in the initial arterial inflow phase $(A-B)$, an oscillometer record of these two observations would be erroneously interpreted as demonstrating an increase in net arterial blood flow. Hewlett and Van Zwaluwenburg (3) called attention to this same error in volume pulse recorders (oscillometers) in 1913. We raise the point again to emphasize an important observation which has been overlooked or forgotten by numerous investigators. 


\section{Resting blood flow studies}

When the foot and leg are exposed to a temperature of $45^{\circ} \mathrm{C}$. for 30 minutes extraneous influences on the minute volume of blood flow are minimized. Table I shows that under these conditions the minute volume of blood flow does not deviate more than 6 per cent from the mean. A glance at the resting values for blood flows in Tables III, IV, V, VI, VII and VIII reveals only slightly larger variations in the unheated leg, suggesting that the foot and leg (more so than the foot alone) represent a more stable vascular bed than heretofore believed.

The same tables also show the well-known large variations in values for resting blood flows obtained in different individuals, even when determined under quite similar conditions. Resting blood flow determinations in the same individual
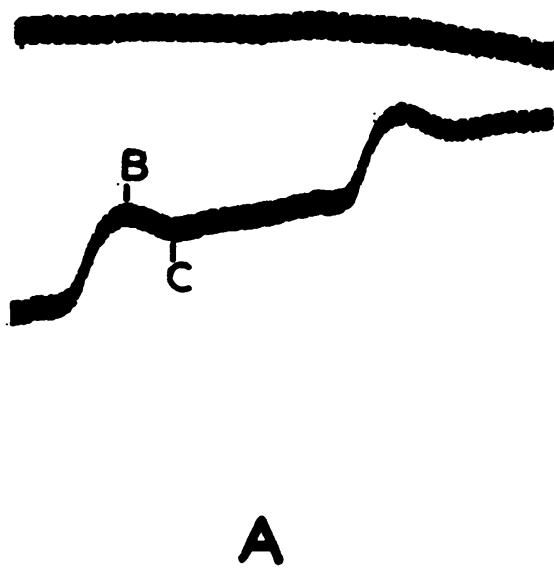

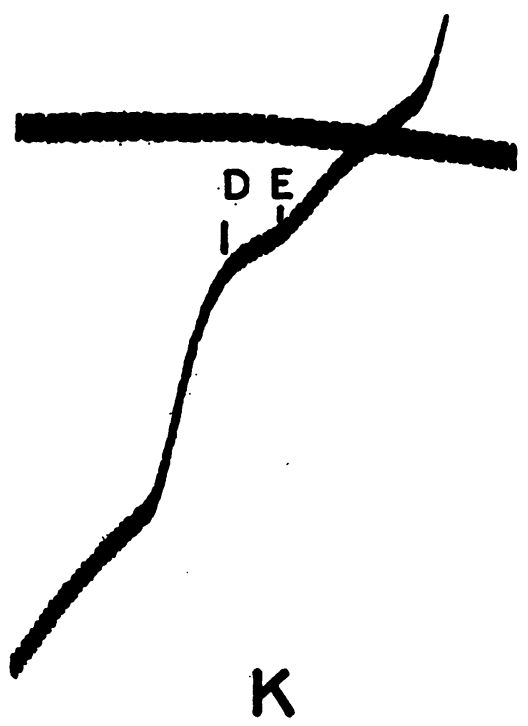

Fig. 4. The Phasic Blood Flow $A$. Before and $K$. After local Heat in the Same Individual

$B-C$. Phase of arterial backflow.

$D-E$. Absence of arterial backflow.
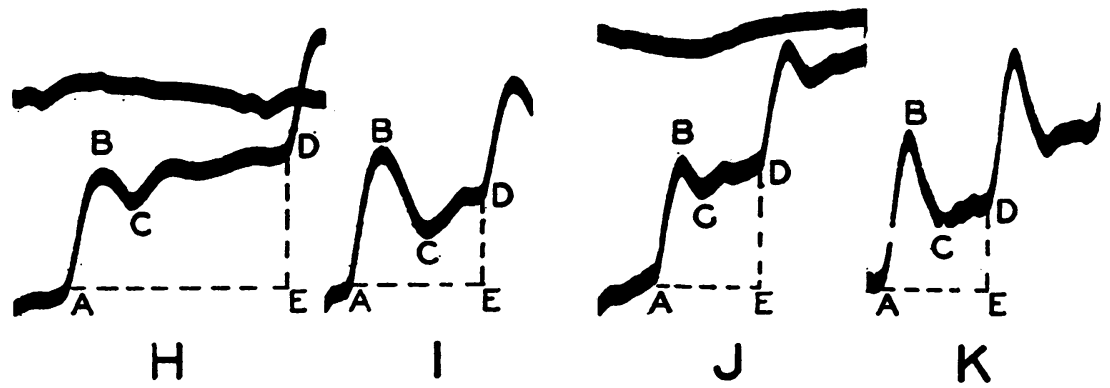

Fig. 5. The Effect of Amyl Nitrite and Sacral Diathermy upon Phasic Blood Flow

$H$. Normal resting flow.

I. Same individual after inhaling amyl nitrite.

$J$. Normal resting flow.

$K$. Same individual after sacral diathermy.

$A-B$. Rapid arterial inflow phase.

$B-C$. Arterial backflow phase.

$C-D$. Slow arterial inflow phase.

$D-E$. Net arterial inflow. 
TABLE IV

Effect of the heat reflex on leg-foot blood flow RESTING BLOOD FLOW

\begin{tabular}{c|c|c|c|c|c|c|c|c}
\hline \hline Time & $\begin{array}{l}\text { Blood } \\
\text { flow }\end{array}$ & $\begin{array}{c}\text { Blood } \\
\text { pres- } \\
\text { sure }\end{array}$ & $\begin{array}{c}\text { Heart } \\
\text { rate }\end{array}$ & $\begin{array}{c}\text { Room- } \\
\text { tem- } \\
\text { pera- } \\
\text { ture }\end{array}$ & $\begin{array}{c}\text { Bath } \\
\text { tem- } \\
\text { pera- } \\
\text { ture }\end{array}$ & $\begin{array}{c}\text { Boot } \\
\text { tum- } \\
\text { pera- } \\
\text { ture }\end{array}$ & $\begin{array}{c}\text { Oral } \\
\text { tem- } \\
\text { pera- } \\
\text { ture }\end{array}$ & $\begin{array}{c}\text { Cuff } \\
\text { pres- } \\
\text { sure }\end{array}$ \\
\hline $3: 31$ & 1.8 & $106 / 70$ & 82 & 29.8 & 30 & 30 & 37.3 & 70 \\
$3: 38$ & 2.0 & $106 / 70$ & 82 & 29.8 & 30 & 30 & 37.3 & 70
\end{tabular}

3:45-UPPER EXTREMITIES IMMERSED IN WATER AT 45 DEGREES CENTIGRADE

\begin{tabular}{|c|c|c|c|c|c|c|c|c|}
\hline $\begin{array}{l}4: 22 \\
4: 26 \\
4: 36\end{array}$ & $\begin{array}{l}3.8 \\
3.9 \\
4.2\end{array}$ & $\begin{array}{l}108 / 72 \\
108 / 72 \\
108 / 72\end{array}$ & $\begin{array}{l}89 \\
92 \\
89\end{array}$ & $\begin{array}{l}29.8 \\
29.8 \\
29.8\end{array}$ & $\begin{array}{l}30 \\
30 \\
30\end{array}$ & $\begin{array}{l}30.5 \\
30.5 \\
30.5\end{array}$ & $\begin{array}{l}37.3 \\
37.3 \\
37.3\end{array}$ & $\begin{array}{l}70 \\
70 \\
70\end{array}$ \\
\hline \multicolumn{9}{|c|}{$\begin{array}{l}\text { 4:45-WATER BATH OF PLETHYSMOGRAPH } \\
45 \text { DEGREES CENTIGRADE }\end{array}$} \\
\hline $\begin{array}{l}5: 17 \\
5: 19 \\
5: 23\end{array}$ & $\begin{array}{l}6.9 \\
6.9 \\
6.8\end{array}$ & $\begin{array}{l}102 / 68 \\
102 / 68 \\
104 / 72\end{array}$ & $\begin{array}{l}92 \\
89 \\
89\end{array}$ & $\begin{array}{l}30 \\
30 \\
30\end{array}$ & $\begin{array}{l}45 \\
45 \\
45\end{array}$ & $\begin{array}{l}44 \\
44 \\
44\end{array}$ & $\begin{array}{l}37.3 \\
37.3 \\
37.3\end{array}$ & $\begin{array}{l}70 \\
70 \\
70\end{array}$ \\
\hline
\end{tabular}

TABLE V

Effect of sciatic nerve block on leg-foot blood flow RESTING BLOOD FLOW

\begin{tabular}{c|c|c|c|c|c|c|c|c}
\hline \hline Time & \begin{tabular}{c|c|c|c|c|} 
Blood \\
flow
\end{tabular} & $\begin{array}{c}\text { Blood } \\
\text { pres- } \\
\text { sure }\end{array}$ & $\begin{array}{c}\text { Heart } \\
\text { rate }\end{array}$ & $\begin{array}{c}\text { Room- } \\
\text { tem- } \\
\text { pera- } \\
\text { ture }\end{array}$ & $\begin{array}{c}\text { Bath } \\
\text { tem- } \\
\text { pera- } \\
\text { ture }\end{array}$ & $\begin{array}{c}\text { Boot } \\
\text { tem- } \\
\text { pera- } \\
\text { ture }\end{array}$ & $\begin{array}{c}\text { Oral } \\
\text { tem- } \\
\text { pera- } \\
\text { ture }\end{array}$ & $\begin{array}{c}\text { Cuff } \\
\text { pres- } \\
\text { sure }\end{array}$ \\
\hline $2: 40$ & 3.0 & $108 / 72$ & 80 & 27 & 27 & 28 & 37 & 75 \\
$2: 45$ & 2.9 & $112 / 70$ & 80 & 27 & 27 & 28 & 37 & 75 \\
$2: 50$ & 3.2 & $112 / 70$ & 80 & 27 & 27 & 28 & 37 & 75
\end{tabular}

SCIATIC NERVE BLOCKED WITH 10 PER CENT PROCAINE (COMPLETE MOTOR AND SENSORY)

\begin{tabular}{l|l|l|l|l|l|l|l|l}
$3: 45$ & 6.0 & $112 / 70$ & 71 & 27 & 27 & 30 & 37 & 75 \\
$3: 57$ & 5.5 & $108 / 70$ & 67 & 27 & 27 & 30 & 37 & 75 \\
$4: 00$ & 6.2 & $108 / 70$ & 71 & 27 & 27 & 30 & 37 & 75 \\
$4: 10$ & 6.2 & $108 / 70$ & 74 & 27 & 27 & 30 & 37 & 75
\end{tabular}

4:30-WATER BATH OF PLETHYSMOGRAPH CHANGED TO 45 DEGREES CENTIGRADE

\begin{tabular}{l|l|l|l|l|l|l|l|l}
$5: 05$ & 6.3 & $108 / 66$ & 77 & 27 & 45 & 44 & 37 & 70 \\
$5: 15$ & 6.3 & $108 / 66$ & 76 & 27 & 45 & 44 & 37 & 70 \\
\hline
\end{tabular}

on different days under non-basal conditions (Table VIII) show no constancy whatever, but under strictly basal conditions (Table VIII) the same individual shows a remarkably constant resting blood flow. This emphasizes the importance of observing such basal conditions when making blood flow determinations on the same individual for comparative purposes.
Minute blood flow in response to vasodilating procedures

The response of the peripheral vascular bed to vasodilating procedures frequently furnishes valuable clinical information regarding their capacity for further dilatation. We have compared the effect of five such procedures in normal healthy young men and have studied the constancy of the reaction of the one producing the maximum vasodilatation. The methods studied are: $(a)$ heat reflex method of Gibbon and Landis (6), (b) sciatic nerve block (7), (c) spinal anesthesia (8),

TABLE VI

Effect of spinal anesthesia on leg-foot blood flow RESTING BLOOD FLOW

\begin{tabular}{c|c|c|c|c|c|c|c|c}
\hline \hline Time & $\begin{array}{l}\text { Blood } \\
\text { flow }\end{array}$ & $\begin{array}{c}\text { Blood } \\
\text { pres- } \\
\text { sure }\end{array}$ & $\begin{array}{c}\text { Heart } \\
\text { rate }\end{array}$ & $\begin{array}{c}\text { Room- } \\
\text { tem- } \\
\text { pera- } \\
\text { ture }\end{array}$ & $\begin{array}{c}\text { Bath } \\
\text { tem- } \\
\text { pera- } \\
\text { ture }\end{array}$ & $\begin{array}{c}\text { Boot } \\
\text { tem- } \\
\text { pera- } \\
\text { ture }\end{array}$ & $\begin{array}{c}\text { Oral } \\
\text { tem- } \\
\text { pera- } \\
\text { ture }\end{array}$ & $\begin{array}{c}\text { Cuff } \\
\text { pres- } \\
\text { sure }\end{array}$ \\
\hline $3: 07$ & 2.1 & $112 / 72$ & 67 & 28 & 28 & 28.5 & 37.2 & 70 \\
$3: 09$ & 2.3 & $112 / 72$ & 67 & 28 & 28 & 28.5 & 37.2 & 70
\end{tabular}

120 MGM. OF NOVOCAIN CRYSTALS INJECTED INTRATHECALLY AT 2ND LUMBAR WITH COMPLETE MOTOR AND SENSORY PARALYSIS TO AND INCLUDING D12

\begin{tabular}{l|l|l|l|l|l|l|l|l}
$4: 04$ & 2.3 & $102 / 72$ & 57 & 28 & 28.5 & 29.5 & 37 & 70 \\
$4: 06$ & 2.5 & $102 / 72$ & 61 & 28 & 28.5 & 29.5 & 37 & 70
\end{tabular}

4:10-UPPER EXTREMITIES IMMERSED IN WATER AT 45 DEGREES CENTIGRADE

\begin{tabular}{l|l|l|l|l|l|l|l|l}
$4: 44$ & 4.0 & $108 / 72$ & 66 & 28 & 29 & 29 & 37.2 & 70 \\
$4: 49$ & 4.2 & $108 / 72$ & 63 & 28 & 29 & 29 & 37.2 & 70 \\
\hline
\end{tabular}

TABLE VII

Effect of sacral diathermy on foot blood flow RESTING BLOOD FLOW

\begin{tabular}{c|c|c|c|c|c|c|c|c}
\hline \hline Time & $\begin{array}{c}\text { Blood } \\
\text { flow }\end{array}$ & $\begin{array}{c}\text { Blood } \\
\text { pres- } \\
\text { sure }\end{array}$ & $\begin{array}{c}\text { Heart } \\
\text { rate }\end{array}$ & $\begin{array}{c}\text { Room- } \\
\text { tem- } \\
\text { pera- } \\
\text { ture }\end{array}$ & $\begin{array}{c}\text { Bath } \\
\text { tem- } \\
\text { pera- } \\
\text { ture }\end{array}$ & $\begin{array}{c}\text { Boot } \\
\text { tem- } \\
\text { pera- } \\
\text { ture }\end{array}$ & $\begin{array}{c}\text { Oral } \\
\text { tem- } \\
\text { pera- } \\
\text { ture }\end{array}$ & $\begin{array}{c}\text { Cuff } \\
\text { pres- } \\
\text { sure }\end{array}$ \\
\hline $2: 32$ & 4.0 & $104 / 60$ & 64 & 28 & 28 & 28 & 37.2 & 65 \\
$2: 34$ & 4.2 & $110 / 60$ & 68 & 28 & 28 & 28 & 37.2 & 65
\end{tabular}

DIATHERMY 1500 MILLIAMPERES APPLIED OVER SACRUM FOR 30 MINUTES

\begin{tabular}{l|l|l|l|l|l|l|l|l}
$3: 30$ & 2.7 & $106 / 54$ & 67 & 28 & 28 & 29 & 37.8 & 65
\end{tabular}

3:35-WATER BATH OF PLETHYSMOGRAPH CHANGED TO 45 DEGREES CENTIGRADE

\begin{tabular}{l|r|r|l|l|l|l|l|l}
$4: 12$ & 9.7 & $106 / 60$ & 67 & 28 & 45 & 44 & 37.6 & 65 \\
$4: 26$ & 11.7 & $110 / 64$ & 64 & 28 & 45 & 44 & 37.6 & 65 \\
\hline
\end{tabular}


TABLE VIII

Constancy of effect of local heat under basal and non-basal conditions NON-BASAL BLOOD FLOW

\begin{tabular}{|c|c|c|c|c|c|c|c|c|c|}
\hline \multirow{2}{*}{ Subject } & \multicolumn{5}{|c|}{ Resting blood flow } & \multicolumn{4}{|c|}{ Blood flow after local heat } \\
\hline & Date & Time & $\begin{array}{l}\text { Blood } \\
\text { flow }\end{array}$ & $\begin{array}{c}\text { Blood } \\
\text { pressure }\end{array}$ & $\begin{array}{c}\text { Heart } \\
\text { rate }\end{array}$ & Time & $\begin{array}{l}\text { Blood } \\
\text { flow }\end{array}$ & $\underset{\text { pressure }}{\text { Blood }}$ & $\underset{\text { rate }}{\text { Heart }}$ \\
\hline W. Z. & January 10, 1939 & $\begin{array}{l}\text { 8:12 P.M. } \\
\text { 8:15 }\end{array}$ & $\begin{array}{l}5.6 \\
5.2\end{array}$ & $\begin{array}{l}112 / 72 \\
112 / 72\end{array}$ & $\begin{array}{l}72 \\
70\end{array}$ & $\begin{array}{l}\text { 8:56 P.M. } \\
\text { 8:58 } \\
9: 05\end{array}$ & $\begin{array}{l}6.3 \\
6.2 \\
7.2\end{array}$ & $\begin{array}{l}112 / 72 \\
112 / 72 \\
112 / 72\end{array}$ & $\begin{array}{l}60 \\
68 \\
70\end{array}$ \\
\hline W. Z. & January 11, 1939 & $\begin{array}{l}\text { 8:28 P.M. } \\
8: 32\end{array}$ & $\begin{array}{l}7.2 \\
6.7\end{array}$ & $\begin{array}{l}116 / 76 \\
116 / 76\end{array}$ & $\begin{array}{l}71 \\
68\end{array}$ & $\begin{array}{l}\text { 9:33 P.M. } \\
\text { 9:36 } \\
9: 40\end{array}$ & $\begin{array}{l}8.0 \\
7.4 \\
7.6\end{array}$ & $\begin{array}{l}108 / 66 \\
108 / 66 \\
108 / 66\end{array}$ & $\begin{array}{l}71 \\
71 \\
7.3\end{array}$ \\
\hline \multicolumn{10}{|c|}{ BASAL BLOOD FLOW } \\
\hline Subject & Date & Time & $\begin{array}{l}\text { Blood } \\
\text { flow }\end{array}$ & $\begin{array}{c}\text { Blood } \\
\text { pressure }\end{array}$ & $\begin{array}{c}\text { Heart } \\
\text { rate }\end{array}$ & Time & $\begin{array}{l}\text { Blood } \\
\text { flow }\end{array}$ & $\begin{array}{l}\text { Blood } \\
\text { pressure }\end{array}$ & $\begin{array}{l}\text { Heart } \\
\text { rate }\end{array}$ \\
\hline W. Z. & January 13, 1939 & $\begin{array}{l}\text { 9:30 A.M. } \\
9: 32 \\
9: 41\end{array}$ & $\begin{array}{l}2.1 \\
2.1 \\
2.8\end{array}$ & $\begin{array}{l}98 / 66 \\
94 / 64 \\
94 / 64\end{array}$ & $\begin{array}{l}41 \\
50 \\
58\end{array}$ & $\begin{array}{l}\text { 10:23 A.M. } \\
10: 25 \\
10: 35 \\
10: 37\end{array}$ & $\begin{array}{l}4.9 \\
5.0 \\
6.4 \\
5.6\end{array}$ & $\begin{array}{r}98 / 64 \\
98 / 64 \\
102 / 68 \\
102 / 68\end{array}$ & $\begin{array}{l}60 \\
53 \\
63 \\
60\end{array}$ \\
\hline W. Z. & January 14, 1939 & $\begin{array}{l}\text { 9:11 A.M. } \\
9: 13 \\
9: 16\end{array}$ & $\begin{array}{l}2.2 \\
2.1 \\
2.1\end{array}$ & $\begin{array}{l}110 / 70 \\
110 / 70 \\
110 / 70\end{array}$ & $\begin{array}{l}\mathbf{5 7} \\
\mathbf{5 5} \\
\mathbf{5 5}\end{array}$ & $\begin{array}{l}\text { 9:48 A.M. } \\
10: 07 \\
10: 15\end{array}$ & $\begin{array}{l}4.0 \\
5.4 \\
5.2\end{array}$ & $\begin{array}{l}108 / 64 \\
110 / 60 \\
110 / 60\end{array}$ & $\begin{array}{l}62 \\
62 \\
64\end{array}$ \\
\hline \multicolumn{10}{|c|}{ AFTER BREAKFAST BUT NO MUSCULAR ACTIVITY } \\
\hline W. Z. & January 15, 1939 & $\begin{array}{l}\text { 10:40 A.M. } \\
10: 45\end{array}$ & $\begin{array}{l}3.6 \\
3.7\end{array}$ & $\begin{array}{l}110 / 68 \\
110 / 68\end{array}$ & $\begin{array}{l}60 \\
62\end{array}$ & $\begin{array}{l}11: 24 \text { A.M. } \\
11: 40 \\
11: 42\end{array}$ & $\begin{array}{l}5.0 \\
5.6 \\
5.1\end{array}$ & $\begin{array}{l}108 / 70 \\
108 / 70 \\
104 / 76\end{array}$ & $\begin{array}{l}60 \\
67 \\
61\end{array}$ \\
\hline
\end{tabular}

(d) sacral diathermy (10), (e) local heat applied for 30 minutes at $45^{\circ} \mathrm{C}$.

Reflex heat. Table IV shows the typical reaction obtained in 1 of 5 subjects resulting from immersion of the hand and forearm of both upper extremities in water at $45^{\circ} \mathrm{C}$. for 30 to 45 minutes. In each individual this procedure produced an unquestionable increase in blood flow above the resting level. When this was immediately followed by local heat applied to the leg in the plethysmograph, a further marked increase was obtained in each instance.

Sciatic nerve block. Blocking the vasomotor fibers in the sciatic nerve (Table V) produced in each of 5 subjects a marked increase in blood flow as compared to the resting minute volume. In no case did reflex heat or local heat in the presence of sciatic nerve block produce a further increase in blood flow.

Sacral diathermy. Of 3 subjects studied by applying diathermy (1500 M.A.) to the sacral area, 2 showed an actual decrease and 1 a very slight increase in blood flow (Table VII). All 3 responded with an increase in blood flow upon the application of reflex heat immediately after the diathermy.

Spinal lumbar anesthesia. Table VI shows the effects upon blood flow in the foot and leg produced by spinal anesthesia from $\mathrm{T}-12$ down. Complete motor and sensory paralysis was present in all 3 of the subjects so studied, 1 other having the same level of anesthesia and the third with anesthesia extending up to $T-10$. In no case did we find any evidence of an increase in blood flow as compared to the resting level. In each case heating the upper extremities produced an increase in blood flow in the presence of the motor and sensory paralysis due to the spinal anesthesia.

Local heat. It is apparent from the foregoing tables that the maximum dilatation occurs in response to local heat and to sciatic nerve block. ${ }^{2}$

2 We realize that other procedures such as muscular exercise and reactive hyperemia might cause a much greater vascular dilatation but, for obvious reasons, they 
In the 5 subjects studied, our observations show that local heat and sciatic nerve block, when applied separately, yield the same blood flow response per individual within narrow limits, providing the conditions under which the measurements are done are comparable.

If local heat is to be used as the stimulating agent, the constancy of its response must be known. A series of studies on the same individual (Table VIII) shows that, under non-basal conditions after a day of ordinary activity, the response to local heating is fairly constant. This equality of response, however, is conditioned by one very important observation, as shown in Table VIII. The same subject was studied on 2 days under strictly basal conditions and on the third day under basal conditions so far as activity was concerned, but following the ingestion of a light meal. On all 3 days the response to local heat was in very close agreement but of significantly less magnitude than after a day of muscular activity. Apparently, muscular activity conditions the response of the peripheral vascular bed to the stimulus of local heat. Studies made upon the same individual on different days for comparative purposes must take this into account. It is preferable to do all measurements under strictly basal conditions.

DISCUSSION OF RESULTS OF DILATING PROCEDURES

We conclude that local heat for 30 to $45 \mathrm{~min}$ utes at $45^{\circ} \mathrm{C}$. can be substituted to advantage for the somewhat more formidable procedure of sciatic nerve block to produce maximal peripheral vascular dilatation, at least in normal individuals. The application of this conclusion to diseased vascular beds remains to be tested. It is conceivable that vessels which are damaged or under the control of an abnormal autonomic nervous system may not have the same response to local heat as those in normal individuals. We also noted that the blood pressure and heart rate fluctuate more in response to local heat than to sciatic nerve block.

Our results with spinal anesthesia appear to be at variance with those of Morton and Scott

would not be suitable agents for studying diseased vascular beds. Moreover, the blood pressure and heart rate changes accompanying exercise and the difficulty of controlling the amount and rate of work done would seriously complicate the interpretation of the results obtained.
(8) and of Brill and Lawrence (9) who report an increase in blood flow in the foot under similar conditions of spinal anesthesia. An elevation of foot skin temperature was used by them as a measure of increase in blood flow. A possible explanation of our differences might be found in the fact that their subjects were studied in a room with a temperature much lower than ours so that the blood flow of their subjects would be expected to be much less than that of our subjects at the beginning of the experiment. In fact, the skin temperature of our subjects was 31 to $32^{\circ} \mathrm{C}$. on the dorsum of the foot at the beginning of our experiments, a skin temperature virtually equal to that obtained in the subjects of Morton and Scott (8) after spinal anesthesia. For this reason, it appears possible that our subjects at rest before spinal anesthesia had blood flows essentially as great as the subjects of Morton and Scott after spinal anesthesia. Such evidence implies that spinal anesthesia does not give complete vasomotor nerve block. This implication finds support in the fact that reflex heat produces an increase in blood flow in the presence of complete skeletal motor and sensory anesthesia. Since spinal anesthesia does not produce an increase in blood flow equal to that resulting from sciatic nerve block, and since reflex heat is effective in the presence of spinal anesthesia, it is reasonable to assume that at least a part of the fibers mediating vasomotor impulses to the lower extremity is intact in its presence. Of the various explanations that might be offered for this situation, none have sufficient experimental evidence supporting them to warrant their exposition.

In regard to the use of skin temperatures as a means of studying variations in blood flow, two observations merit attention. We have measured the blood flow in many subjects with skin temperatures of 32 to $33^{\circ} \mathrm{C}$., finding values of only $2 \mathrm{cc}$. per $100 \mathrm{cc}$. per minute. In other words, a relatively small blood flow will sometimes maintain a normal skin temperature. Also, 1 subject having a foot skin temperature of $35^{\circ} \mathrm{C}$. with a blood flow of $3 \mathrm{cc}$. per $100 \mathrm{cc}$. per minute, showed a further rise of only $1^{\circ} \mathrm{C}$. (to $36^{\circ} \mathrm{C}$.) when the blood flow increased to $10.0 \mathrm{cc}$. per $100 \mathrm{cc}$. per minute following sciatic nerve block. These observations suggest that skin temperature deter- 
minations mirror the changes in blood flow up to a point beyond which the blood flow may increase greatly with but little further rise in skin temperature.

Our results with sacral diathermy do not support those reported by de Takats (10) who based his evidence for an increase in blood flow through the foot upon skin temperature determinations. Skin temperature studies are in this particular instance very untrustworthy since the body temperature is elevated $\left(1^{\circ} \mathrm{C}\right.$. or more) and also since the blood flowing to the skin of the leg may be warmed as it flows through the pelvis via the iliac arteries. The actual decrease obtained in 2 subjects may be due to dilatation of visceral vascular beds in the lower abdomen with a consequent shunting of blood into these areas.

\section{SUMMARY AND CONCLUSIONS}

1. Despite many advantages of the HewlettVan Zwaluwenburg plethysmographic method for determining blood flow in the limbs, this procedure -and even more its modification by subsequent workers-has a number of hidden faults which lead to inaccuracies in the estimation of flow under different conditions. Among these are: the yielding diaphragm surrounding the limb and closing the plethysmograph, displacement of fluid into the plethysmograph by inflation of the collecting cuff, and lack of sensitivity of the entire apparatus.

2. A boot plethysmograph is described which is easy to apply and calibrate, the open end of which is sealed around the leg without constriction by the use of plaster of paris and Unna paste, and which is comfortable for prolonged periods of study. The apparatus is connected to a Frank segment capsule giving the entire system frequencies up to 100 per second.

3. To obviate the artefacts incurred through displacement of fluid into the plethysmograph by the inflated cuff, an arrangement of stopcocks is provided by which the collecting cuff is inflated while the plethysmograph and recording capsule remain open to the atmosphere; but exactly one second later it is automatically closed and the volume changes are recorded. The rise of a full pulse beat starting exactly 1.6 seconds after inflation is used to measure the net flow per cycle. From this the volume flow per minute per $100 \mathrm{cc}$. of leg substance is calculated in the conventional manner.

4. The phasic arterial blood flow of the leg recorded in this way for normal subjects at rest in a warm room $\left(28^{\circ}\right.$ to $30^{\circ}$ C. $)$, shows three distinct variations during each cycle: (1) a rapid systolic forward flow, (2) a slower smaller and variable systolic backflow, (3) a slow forward flow during diastole. The net arterial inflow depends not only on 1 plus 3 but also upon the amount subtracted by 2 . All of these vary under different circumstances. Since only the amplitude (phase 1 above) of the pulse volume is recorded by plethysmographs or oscillometers, these methods give no quantitative estimate of changes in volume flow, and under some conditions they do not even show the correct directional changes.

5. The resting flow determined by our procedure remains constant within approximately 6 per cent of the mean during repeated determinations within an hour. It varies greatly in different individuals or in the same individual from day to day unless strictly basal conditions are observed.

6. A study of various procedures suggested for promoting a maximal blood flow in the leg shows that direct application of heat and sciatic nerve block are the most efficacious. Application of heat to both upper extremities (reflex heat) produces an effect only about one-half as great. We were unable to detect any increase in blood flow following effective spinal anesthesia or sacral diathermy.

7. Other procedures which affect heart rate or blood pressure significantly influence blood flow in a variable manner. Amyl nitrite, for example, increases the amplitude of oscillations but often causes an actual decrease in volume flow.

We wish to thank Professor Carl J. Wiggers for his very helpful criticism and aid in preparing this manuscript. We also wish to acknowledge the technical assistance of Mr. William Zantiny, and to express our appreciation to Messrs. B. S. Brown, M. Fisher and D. E. Kirkham, who served as subjects for the most exacting of the foregoing studies.

\section{BIBLIOGRAPHY}

1. Hewlett, A. W., and Van Zwaluwenburg, J. G., Method for estimating the blood flow in the arm. Arch. Int. Med., 1909, 3, 254.

2. Brodie, T. G., and Russell, A. E., On the determina- 
tion of the rate of blood flow through an organ. J. Physiol. (Proc.), 1905, 32, 47.

3. Hewlett, A. W., and Van Zwaluwenburg, J. G., The pulse flow in the brachial artery; I. Technic and general considerations. Arch. Int. Med., 1913, 12, 1.

4. Hamilton, W. F., and Dow, P., An experimental study of the standing waves in the pulse propagated through the aorta. Am. J. Physiol., 1939, 125, 48.

5. Hamilton, W. F., Woodbury, R. A., and Harper, H. T., Jr., Physiologic relationships between the intrathoracic, intraspinal and arterial pressures. J. A. M. A., 1936, 107, 853.

6. Gibbon, J. H., Jr., and Landis, E. M., Vasodilatation in the lower extremities in response to immersing the forearms in warm water. J. Clin. Invest., 1932, 11, 1019.

7. White, J. C., Diagnostic blocking of sympathetic nerves to the extremities with procaine; test to evaluate the benefit of the sympathetic ganglionectomy. J. A. M. A., 1930, 94, 1382.

8. Morton, J. J., and Scott, W. J. M., The measurement of sympathetic vasoconstrictor activity in the lower extremities. J. Clin. Invest., 1930, 9, 235.

9. Brill, S., and Lawrence, L. B., Changes in temperature of the lower extremities following induction of spinal anesthesia. Proc. Soc. Exper. Biol. and Med., 1930, 27, 728.

10. de Takats, G., The differentiation of organic and spastic vascular occlusions. Ann. Surg., 1931, 94, 321. 